\title{
Changes in Community Structure and Species Diversity of Water Birds as Ecological Indexes of Hor-Al-Azim Marsh
}

\author{
'Behrouz Behrouzi-Rad \\ Retired from Department of Environment of Iran, Wildlife Ecology Specialist,Iran \\ "Corresponding Author: Behrouz Behrouzi-Rad, Retired from Department of Environment of Iran, Wildlife \\ Ecology Specialist,Iran, Email: bbehrouzirad@yahoo.com \\ Received Date: 17 December, 2018; Accepted Date: 05 February, 2019; Published Date: 15 February 2019
}

\section{Abstract}

Diversity variations, community structure, and biodiversity indexes of water birds are a good indicator of the ecological function of the wetlands ecosystems. Counting the water bird's community using the total count method with a $15 \times 60$ telescope and a $10 \times 4$ Zeiss binocular in February 2006, 2011 and 2016. Globaly threatened species are identified by the IUCN (IUCN, 2015) criteria and protected species in Iran by the Department of Environment, Iran, rules, and standards. Hor-al-Azim wetland water bird's community consisted of two types of water beds, swimmers with 21 species and shore birds with 30 species. The total number of water beds in the Hor-al-Azim in February 2006 with an area of 118,000 ha, 2011 with an area of 5000 ha., and 2016 with an area of 10,000 ha., were 18337 individuals belonging to 51 species, 2257 individuals with 33 species and 3914 individuals with 43 species respectively. Margalef species diversity for all water beds of the wetland (aquatic swimmer and shorebirds) in February 2006, 2011, and 2016 were, 5.078, 4.139, and 5.093, respectively, for shorebirds were 3.296, 3.292, and 3.245 and for swimmer aquatic birds, were $2.264,1.830$, and 0.648 respectively. The decline in the water beds has been $87.7 \%$ since 2006 to 2011, and $78.66 \%$ from 2006 to 2016 . The number of species decreased from 51 species in 2006 to 35 species in 2011 (reduction was $31.38 \%$ ) and from 2006 to 2016 reduction was 8 species (15.69\%). Changes in biodiversity indicators have also been considerawable. The main reason for reducing the number of birds and species diversity was the drying of the wetland from 2006 to 2016 . The reason for drying the wetland is, drought, harvesting water in the uplands and constructing dam on the rivers (The area of the wetland decreased from 118,000 ha to 10,000 ha, which reduction was $91.53 \%$.

\section{Keywords}

Ecological changes; Community of water birds; Hor-al-Azim; wetland Ecosystem

\section{Introduction}

In the world for several decades, the structure of the community and the diversity of wetland birds are considered as indicators of the ecological function of the wetlands [1-3]. In Iran, since 1969, the counting and determination of the populations of water birds in Iranian wetlands is carried out by the Department of Environment of Iran. The Hor-al-Azim wetland is a part of the permanent wetlands in the eastern Mesopotamia in Khuzestan province, on the border between Iran and Iraq. The wetlands area varied from 500000 to 300000 hectares [4]. In Iran varied from 300,000 to 118000 hectares. Diversity variations, populations, biodiversity and aquatic animal densities as well as water birds are a good indicator for determining the ecological conditions of wetland ecosystems [5]. Iran has 250 wetlands with an area of about 2.5 million hectares [6,7]. Among them, 24 wetlands with a total area of 148,638 hectares have been registered at the Ramsar Convention. In the world by June 2016, 2200 wetlands in 169 countries with a total area of $219,175,951$ hectares have been listed on the Ramsar Convention List [8]. The area of the 24 international wetlands in Iran is $0.68 \%$ of the area of the world's international importance wetlands. Hor-al-Azim wetland is one of the major wetlands in Khuzestan province in southwest of Iran, which was protected in 2011, and proposed to be registered in the list of international wetlands ratified by the Convention. [9]. since 1994, it has been listed in the Important Birds Area (IBA) [10]. In assessing the Iranian wetlands by the Department of Environment of Iran, based on the criteria of the water birds population, Horal-Azim was in the first in 2004 before drying. [11]. On the other hand, Iranian wetlands, including Hor-al-Azim, in West Asia, are of particular importance for the survival and conservation of a large number of wintering and breeding water birds [12]. In addition to wintering water birds 11 species of water birds were globally threatened such as Ferruginous Duck Aythya nyroca and Marbled Teal marmaronetta angustirostris [13], and two native species of Mesopotamia marshes (Little Grebe Tachybaptus roficollis and Darter Anhinga rufa) were reported [14]. On the 
Citation: Behrouz BR (2019) Changes in community structure and species diversity of water birds as ecological indexes of Hor-al-Azim Marsh. J Aquat Res Mar Sci 2019: 134-144.

other hand, the mudflats of the Hor-al-Azim wetland is important habitat for wintering and conserving of protected species in Iran such as White Stork ciconia ciconia, and seven species of Ardeidae [15]. After drying much parts of the Hor-al-Azim in last years, a number of species have been eliminated and some have also reduced population. An overview of the population of water birds in Iran's wetlands shows that in 1970, 12 million water birds were migrating to Iran's wetlands, decreasing by 3-4 billion water birds in 2016 [16], Drying wetlands and their ecological changes reduce the population of water birds. For this reason, changes in the population of water birds are the ecological indicators of wetlands. In the world, many studies have been done on water birds population and species diversity as an ecological indicator of wetlands, including. Bechir et al. (2013) [17], Musgrove et al. (2011) [18] Rotenberry (1985) [19] and Torres (1995) [20]. Yahkat et al. (2017) [21]. In Iran well-known studied of Variety and density of water birds in southern wetlands at Caspian Sea coasts [22], the preparation of ecological view of Hor-al-Azim wetland [23]. Contrasting changes in the abundance and diversity of Northern Iranian birds' assemblages from 2011 to 2015 [24]. Migratory waterfowls as indicators to assess the protection efficiency in Iran [25]. Classifications of Iranian wetlands are noted [11]. The purpose of this study was to investigate the variation of species diversity and the structure of the water birds communities in Hor-al-Azim during wet and dry periods and to change the land use of Hor al-Azim wetland. Because the changes in the structure of the population and species diversity of water birds in wetlands are a significant indicator of the changes in the ecological status of the wetlands

\section{Materials and Methods}

Hor-al-Azim or Hor-al-Hoveizeh is part of the permanent wetland of Mesopotamia marshes located in the west of Khuzestan province at the end of the Karkheh River in Azadegan plain between the two countries of Iran and Iraq at a geographical location of $31^{\circ} 53^{\prime} \mathrm{N} 47^{\circ} 16^{\prime} 30^{\prime \prime} \mathrm{E}$ in near cities of Bostan, Howeizeh and Rofaie $[4,14]$. The area of the Hor-al-Azim has been reported to be 500000 to 300000 hectares [2,4, and 14]. 300000-118,000 hectares (about 30 percent) are located in Iran. The main source of water supply is surface waters, mainly the Tigris and Karkheh rivers. Figures 1 and 2 show the status and changes of the wetland between 1987 and 2016. The average annual rainfall is 119 $\mathrm{mm}$, and average temperatures is $24^{\circ} \mathrm{C}$ [23]

The eastern boundary of Hor-al-Azim, on the Iran, extends from the west of the city of Bostan to Tang-e- Chazbeh and extends to the south to Shat Ali by a length of about $50 \mathrm{~km}$. The access road to the wetland starts from north of $5 \mathrm{~km}$ after crossing the bridge of Hoffel in Bostan to the west of the wetland. At Tang-e Chazbeh,turn $90^{\circ}$ to the south, about $50 \mathrm{~km}$ along the path of Shahid Bakeri and Shahid Hemmat roads to the southern part of the wetland, Shat Ali road comes in the 2000 dedicate, the wetland was filled with water and in the decade of 2011 the vast majority of dry wetlands and an area of about 5000 hectares and in 2016 the area of the wetland with the amount of water flowing from the flood waters and Karkheh overflow had reached about 10,000 hectares, (Figures 2 and 3).

\section{Data Collection}

Water birds' counting was carried out on 15 February 2006, on 17 February 2011, and on 18 February 2016, with a $10 \times 40$ binoculars and a $15 \times 60$ telescope with total count method, by walking along the paths around the wetland, by car on the roads that constructed by Oil Company and by boat on the open water of marsh. The Wetlands International used and recommended this method for counting wetland birds in the world's wetlands since 1969 [26]. For this reason, the counting of water birds in the Hor-

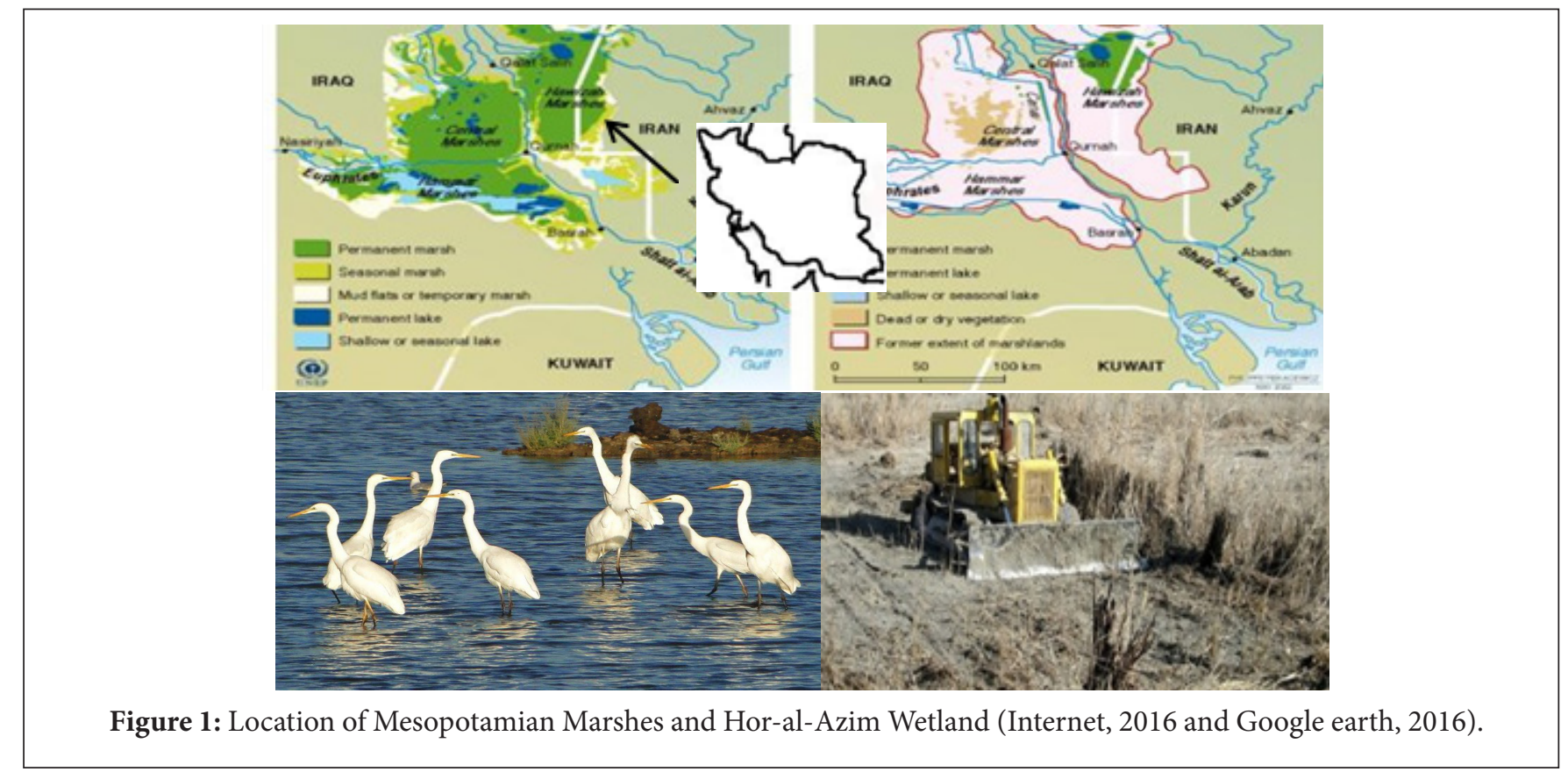

J Aquat Res Mar Sci 2019: 134-144. 


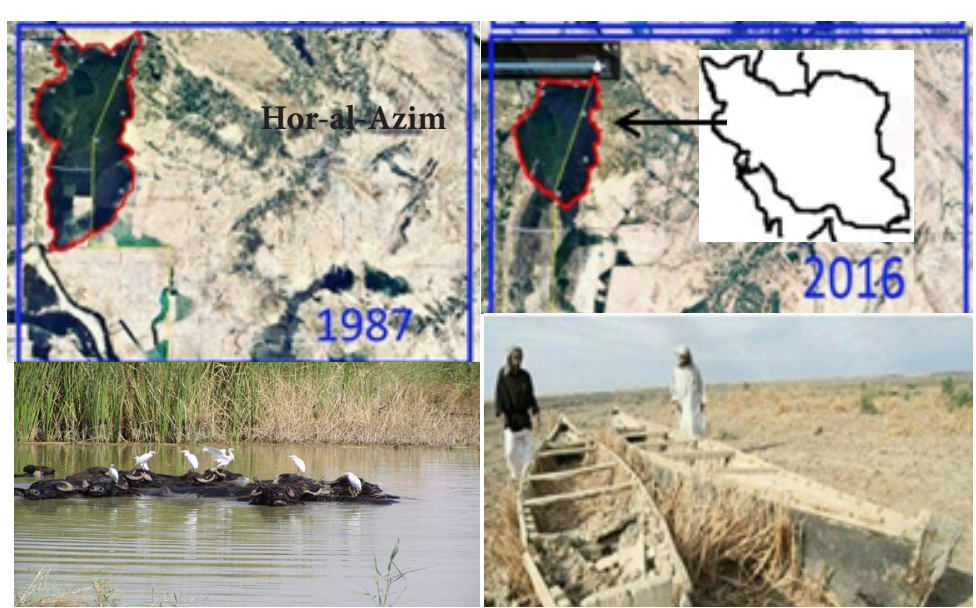

Figure 2: Variation of Mesopotamian wetlands and Hor-al-Azim 1987 to 2016 (Google earth, 2016)

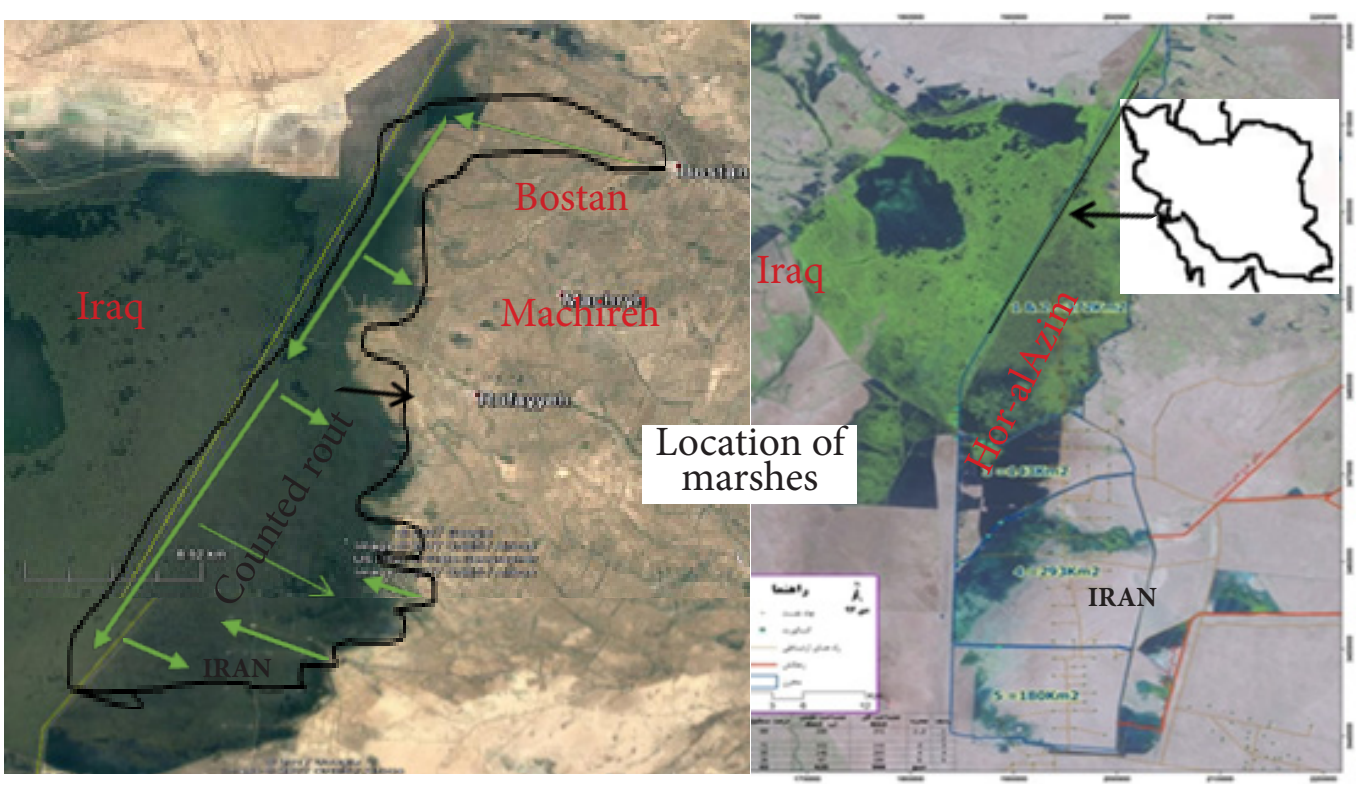

Figure 3: Location of Hor-al-Azim and water birds count routs (Google Earth, 2016)

al-Azim has been carried out with a total count method. The path of counting water birds every three years from the north of the marsh from Tang-e Chazbeh to its south Shat Ali on the roads of Shahid Hemmat, Imam Reza, Shahid Bakeri and roads built by the oil company in the southern part and inside the wetland, as well as by boat on open water of wetland, which remained intact due to the drying of the wetland into small and interrupted ponds, it was carried out on the same day from 8 am to $4 \mathrm{pm}$. Water birds were identified using the Field Guide to the Asian Water birds [27]. The biodiversity indicators calculated in this study were

Shanon-Winnier $\quad H^{\prime}=-\sum_{i=1}^{s} \operatorname{Pi} \operatorname{Ln}(P i)$

Simpson dominance $1-\mathrm{D}=1-\sum_{\mathrm{i}=1}^{\mathrm{s}}\left[\frac{\mathrm{ni}(\mathrm{ni}-1)}{\mathrm{N}(\mathrm{N}+1)}\right]$
Margalef and Mehinck richness $R=\frac{S-1}{\operatorname{LnN}}, \quad \mathrm{D}_{\mathrm{mn}}=\frac{\mathrm{S}}{\sqrt{\mathrm{N}}}$

Species evenness $\quad \mathrm{E}=\frac{\mathrm{H}^{\prime}}{\operatorname{Ln}(\mathrm{S})}$

Berger-Parker evenness $d=\frac{N \max }{\mathrm{N}}$

Brillouin $\mathrm{Hg}=\frac{1}{\mathrm{~N}} \log \left(\frac{\mathrm{N} !}{\mathrm{n} 1 ! \mathrm{n} 2 ! \mathrm{n} 3 ! \ldots . .}\right)$

Equitability $\quad \mathrm{E}=\frac{\mathrm{H}^{\prime}}{\operatorname{Ln}(\mathrm{S})}$

Fisher-alpha $S=a \ln (1+\mathrm{n} / \mathrm{a})$ 
Citation: Behrouz BR (2019) Changes in community structure and species diversity of water birds as ecological indexes of Hor-al-Azim Marsh. J Aquat Res Mar Sci 2019: 134-144.

Alpha, Beta, and Gamma diversity have been used by Whitaker (1972), a Diversity is the variety of species found in a community, habitat, or specific ecosystem, $\beta$ diversity $\beta_{r}=\frac{G+\mathbf{L}}{2 \mathbf{a}}$ and $\gamma$ diversity is the richness of a range of habitats in a geographic region and percentage similarity coefficient and Euclidean difference measured with Past Software [28]. Globally threatened species distinguished by the IUCN 2010 criteria's, and protected species in Iran are distinguished Department of Environment of Iran rules [16].

\section{Results}

In total, in February 2006, 2011 and 2016, 18337 individuals belonged to 51 species, 2257 individuals belonged to 33 species and 3914 individuals belonging to 43 species reported respectively (Table 1). Figure 4 shows that the number of birds counted in 2006 was 4.16 times in 2016 and 8.12 times in 2011 and the relative frequency of birds was 75\% in 2006 (wet year), 9\% in 2011 (drought) and 16\% in 2016. Distribution, numbers, density and diversity, alpha, beta, and gamma diversity and density of water birds in the wetland is shown in table 1 . The number of water birds species decreased by $15.69 \%$ from 2006 to 2016 .

Fifty-one species of water birds identified in Hor-al-Azim were classified into two groups:

1- Swimmer water birds, this group are swimmer

2- Shore birds (Waders and wading) are not swimmers and live on the shores of the water ecosystems

\section{Swimmer water birds}

Total number of swimmer water birds was 10720, on February 2006 which decreased by $80.4 \%$ to 2102 on February 2011, with a decrease of $73.55 \%$ to 2836 individuals in February 2016. (Tables 1). The average reduction in swimmer water birds from 2006 to 2016 was $73.55 \%$ (Table 1). Table 2 shows the Teal Anas crecca in 2006 with $21.10 \%$, in 2011 with 43.08\%, and the Coot Fulica atra in 2016 was the most frequent with $16.72 \%$. Species diversity and biological indices of swimmer water birds have been decreased from 2006 to 2016. The largest decrease was observed in 2011, as most of the wetland was drought (Table 4). The status of the protected, swimmer water birds species, native to the holly wetland and globally threatened species was as follows:

The native species of the Mesopotamian marshes Little Grebe were 219 individuals in 2006 . Decreased by $27 \%$ to 160 individuals in 2011 and decreased by $36.53 \%$ to 139 individuals in 2016 . Darter Anhinga rufa chantrei was not observed in three years of study but reported 2 individuals in 2004 (Panadm Consultant Engineering, 2006). The population of protected species Greater Flamingo Phoenicopterus ruber has dropped by $90 \%$ from 120 individuals in 2006 to 12 individuals in 2016. The population of the Pygmy Cormorant Phalacrocorax pygmeus (Globally threaten species) has been decreased 18\% in 2016 (150 to 123 individuals). The protected and globally endangered species of Marbled Teal were 120 individuals in 2006, but in 2016 only 2 individuals were present in the Hor-al-Azim. Reduction of this species was 98.4\%. Two species Ferruginous Duck (4 individuals) and Shelduck (50 individuals) were present in 2006 but declined to

\begin{tabular}{|l|l|l|l|}
\hline Water birds Group & $\mathbf{2 0 0 6}$ & $\mathbf{2 0 1 1}$ & $\mathbf{2 0 1 6}$ \\
\hline Number of swimmer water birds & 10720 & 2102 Reduction $80.4 \%$ & 2836 Reduction $73.55 \%$ \\
\hline Species number of swimmer water birds & 21 & 15 Reduction $28.58 \%$ & 19 Reduction $9.53 \%$ \\
\hline Number of shore birds (Waders and Wading birds) & 7617 & 155 Reduction $97.97 \%$ & 1078 Reduction $85.85 \%$ \\
\hline Species number shore birds (waders and wading birds) & 30 & 18 Reduction $40 \%$ & 24 Reduction $20 \%$ \\
\hline Total Number & 18337 & $\begin{array}{l}2257 \text { Reduction } \\
87.53 \%\end{array}$ & $\begin{array}{l}3914 \text { Reduction from } \\
200678.68 \%\end{array}$ \\
\hline Area of wetland (In Iran) & 11800 & $\begin{array}{l}5000 \text { ha. 85\%Reduc- } \\
\text { tion }\end{array}$ & $\begin{array}{l}10000 \text { ha. Reduction } \\
69.85 \%\end{array}$ \\
\hline Total Number of species & 51 & 35 Reduction $(37.25 \%)$ & 43 Reduction $11.26 \%$ \\
\hline Density of water birds & 0.55 & 0.45 & 0.39 per hectare \\
\hline$\alpha$ diversity of water birds & 51 & 33 & 43 \\
\hline$\alpha$ diversity of swimmer birds & 21 & 15 & 19 \\
\hline$\alpha$ diversity of waders and wading birds & 30 & 18 & 24 \\
\hline$\gamma$ diversity of total water birds & & & 51 \\
\hline$\beta$ Diversity & $2006-2011$ & $2011-2016$ & $2006-2016$ \\
\hline$\beta$ diversity of total water birds between three years & 0.214 & 0.342 & 0.085 \\
\hline$\beta$ diversity of waders and wading birds between three years & 0.25 & 0.428 & 0.111 \\
\hline$\beta$ diversity of swimmers birds between three years & 0.166 & 0.235 & 0.050 \\
\hline
\end{tabular}

Table 1: Species number, density of water birds and area of Hor-al-Azim in 2006, 2011 and 2016. 
Citation: Behrouz BR (2019) Changes in community structure and species diversity of water birds as ecological indexes of Hor-al-Azim Marsh. J Aquat Res Mar Sci 2019: 134 -144.

\begin{tabular}{|c|c|c|c|c|c|c|c|}
\hline Name of Species & $\begin{array}{l}\text { No. } \\
2006\end{array}$ & $\begin{array}{l}\text { Abundance } \\
2006\end{array}$ & $\begin{array}{l}\text { No. } \\
2011\end{array}$ & $\begin{array}{c}\text { Abundance } \\
2011\end{array}$ & $\begin{array}{l}\text { No. } \\
2016\end{array}$ & $\begin{array}{l}\text { Abundance } \\
2016\end{array}$ & $\begin{array}{l}\text { Population } \\
\text { Reduction } \\
\text { from } 2006 \\
\text { to } 2016\end{array}$ \\
\hline Little Grebe Tachybaptus ruficollis & 219 & $1.20(2.04)$ & 160 & $7.08(7.61)$ & 139 & $3.55(4.90)$ & $36.53 \%$ \\
\hline $\begin{array}{l}\text { Great Crested Grebe podiceps } \\
\text { cristatus }\end{array}$ & 58 & $0.32(0.54)$ & 4 & $0.16(0.19)$ & 12 & $0.30(0.42)$ & $79.32 \%$ \\
\hline $\begin{array}{l}\text { Great Cormorant Phalacrocorax } \\
\text { carbo }\end{array}$ & 1720 & $9.38(16.04)$ & 23 & $1.01(1.09)$ & 12 & $0.30(0.42)$ & $99.31 \%$ \\
\hline Pygmy Cormorant Phalacrocorax & 150 & $0.81(1.39)$ & 90 & $3.95(4.28)$ & 123 & $3.14(4.33)$ & $18 \%$ \\
\hline Slender-billed Gull Larus genei & 155 & $0.84(1.44)$ & 0 & $0(0)$ & 121 & $3.09(2.66)$ & $21.94 \%$ \\
\hline Black-headed Gull Larus ridibundus & 1200 & $6.54(11.19)$ & 56 & $2.45(2.66)$ & 131 & $3.35(4.61)$ & $89.09 \%$ \\
\hline $\begin{array}{l}\text { Greater Flamingo Phoenicopterus } \\
\text { ruber }\end{array}$ & 120 & $0.66(1.11)$ & 0 & $0(0)$ & 12 & $0.30(0.42)$ & $90 \%$ \\
\hline Greylag Goose Anser & 520 & $2.83(4.85)$ & 0 & $0(0)$ & 12 & $0.30(0.42)$ & $97.7 \%$ \\
\hline Shelduck Tadorna & 50 & $0.27(0.46)$ & 0 & $0(0)$ & 0 & $0(0)$ & $100 \%$ \\
\hline Eurasian Wigeon Anas penelope & 20 & $0.10(0.18)$ & 15 & $0.65(0.71)$ & 123 & $3.14(4.33)$ & $\begin{array}{l}615 \% \text { in- } \\
\text { creased }\end{array}$ \\
\hline Gadwall I & 155 & $0.84(1.44)$ & 614 & $26.96(29.21)$ & 321 & $8.20(11.31)$ & $\begin{array}{l}207 \% \text { in- } \\
\text { creased }\end{array}$ \\
\hline Common Teal Anas crecca & 3870 & $21.10(36.10)$ & 981 & $43.08(46.66)$ & 564 & $14.42(19.88)$ & $85.43 \%$ \\
\hline Mallard Anas platyrhynchos & 220 & $1.20(2.05)$ & 10 & $0.44(047)$ & 431 & $11.02(15.19)$ & $\begin{array}{l}195 \% \text { in- } \\
\text { cresed }\end{array}$ \\
\hline Pintail Anas acuta & 13 & $0.07(0.12)$ & 4 & $0.16(019)$ & 12 & $0.30(0.42)$ & $7.7 \%$ \\
\hline Shoveler Anas clypeata & 750 & $4.09(6.99)$ & 75 & $3.29(3.56)$ & 56 & $1.43(1.97)$ & $92.54 \%$ \\
\hline $\begin{array}{l}\text { Marbled Teal Marmaronetta an- } \\
\text { gustirostris }\end{array}$ & 120 & $0.65(1.11)$ & 0 & $0(0)$ & 2 & $0.05(0.07)$ & $98.34 \%$ \\
\hline Pochard Aythya ferina & 213 & $1.16(1.98)$ & 4 & $0.16(0.19)$ & 65 & $1 / 64(2.19)$ & $69.49 \%$ \\
\hline Ferruginous Duck Aythya nyroca * & 4 & $0.02(0.03)$ & 0 & $0(0)$ & 0 & $0(0)$ & $100 \%$ \\
\hline $\begin{array}{l}\text { Common Moorhen Gallinula chlo- } \\
\text { ropus }\end{array}$ & 7 & $0.04(0.6)$ & 2 & $0.08(0.09)$ & 45 & $1.14(1.58)$ & $\begin{array}{l}642 \% \text { in- } \\
\text { creased }\end{array}$ \\
\hline $\begin{array}{l}\text { Purple Swamphen Porphyrio por- } \\
\text { phyria* }^{*}\end{array}$ & 6 & $0.03(0.5)$ & 4 & $0.16(0.19)$ & 1 & $0.02(0.03)$ & $83.34 \%$ \\
\hline Eurasian Coot Fulica atra & 1150 & $6.27(10.72)$ & 60 & $2.63(2.85)$ & 654 & $16.72(23.03)$ & $43.14 \%$ \\
\hline Total Species & $\begin{array}{l}21 \\
\text { species }\end{array}$ & 100 & $\begin{array}{l}15 \\
\text { species }\end{array}$ & 100 & $\begin{array}{l}19 \\
\text { species }\end{array}$ & Total species & $9.53 \%$ \\
\hline Total & 10720 & 100 & 2102 & & 2836 & 100 & $73.55 \%$ \\
\hline
\end{tabular}

Table 2: Number and relative abundance of swimmer water birds in Hor-al-Azim in 2006, 2011 and 201

+ protected in Iran * Globally threatened species

Numbers inside the parentheses are relative abundance of swimmer aquatic birds in the same year

Numbers outside the parentheses are relative abundance of swimmer aquatic birds to total water birds in the same year 
Citation: Behrouz BR (2019) Changes in community structure and species diversity of water birds as ecological indexes of Hor-al-Azim Marsh. J Aquat Res Mar Sci 2019: 134-144.

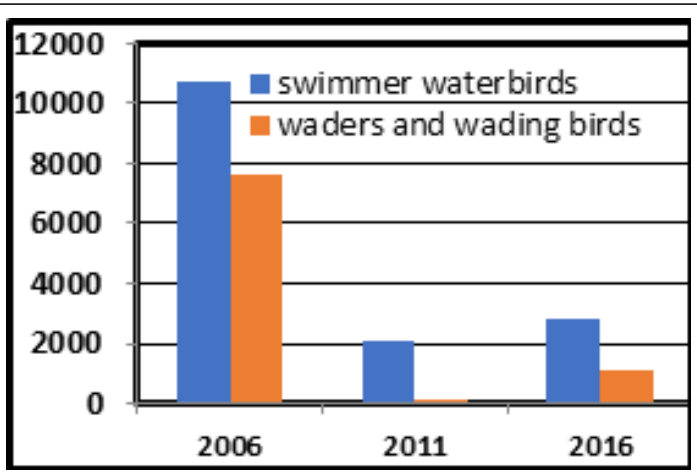

Figure 4: Number of all water birds in three years 2006, 2011, and 2016 in Hor-al-Azi

zero in 2016.

\section{Shore Birds (Waders and wading Birds)}

The number of waders and wading birds were 30 species with a population of 7617 individuals in 2006, 18 species with a population of 155 individuals in 2011(reduction was 97.97\%), and 24 species with a population of 1078 individuals in 2016 (reduction was $85.85 \%$ ) (Table 1 ). The calidris minuta with $12.27 \%$ in 2006 , the Bubulcus ibis with $1.97 \%$ in 2011 and the Vanellus leucurus with $3.99 \%$ in 2016 had heist relative abundance (Table 3). The Threskiornis aethiopicus were 9 in 2006 has dropped to zero in 2016 (reduction was $100 \%$ ). Table 3 shows that the population of 7 species of protected herons in Iran decreased to 386 individuals by $84 / 63 \%$ reduction from 2510 individuals in 2006. Figure 4 shows the relative frequency of birds counted in three study years. Because of the changes in the water birds population from 2006 to 2016, their biodiversity indicators also naturally changed and decreased. Changes in biodiversity indicators of waders and wading birds were similar to those of swimmers water birds, but their decrease was higher than those. Table 4 shows the variations in the biological indices of water birds. Table 4 shows the highest Simpson dominance for all water birds in wetland (swimmers water birds and shore birds) were 0.091 in 2006 reduced to 0.08 in 2016. The highest Margalef variety for all water birds was 5.093 in 2006 for waders and wading birds was 3.296 and for swimmer water birds was 2.264 in 2016 . The highest percentage similarity among swimmer water birds was 51.81 between 2006 and 2016 and the lowest similarity was $49.15 \%$ between 2006 and 2011 . The highest percentage similarity among shore birds was $63.66 \%$ between 2011 and 2016 and the lowest similarity was $37.46 \%$ between 2006 and 2011. The highest Euclidean difference among swimmer water birds was 856.448 between 2006 and 2016. The lowest difference was 49.51 between 2006 and 2011. The highest Euclidean difference between shore birds was between 2006 and 2016 (543.435) and the lowest was between 2011 and 2016 (236.5). In general, the most similarity between the total water birds was between 2006 and 2011 (49.35\%) and the lowest similarity between the total water birds of the wetland was between 2006 and 2011 (40.45\%). The highest Euclidean difference between the total water birds of the wetland was between 2006 and $2011(685 / 697)$ and the least Euclidean difference between the total water birds was between 2011 and 2016 (133.247). Darter (native to Mesopotamia marshes) was observed in 2004 [10,14], but this species was not observed in three study years. Little Grebe is an endemic species of Mesopotamia marshes and Horal-Azim $[4,10]$. Its population reduced $36.53 \%$.

In 2001, 11 globally threatened species were reported in Hor-alAzim $[4,10]$ but only 4 species were observed and reported in three study years (Tables 2 and 3). Seven species of globally threatened species were not observed during three study years. The water bird's population has fallen from 18,337 individuals in February 2006 to 3914 in February 2016. The reduction was $78.66 \%$. The number of species decreased from 51 species on February 2006 to 43 species on February 2016. The reduction was $15.69 \%$. The number of species reported 53 species in Horal-Azim in 1975[12]. Reduction from 1975 to 2015 is $3.78 \%$ The presence of endangered species, such as the Pygmy Cormorant, Ferruginous Duck, Purple Gallinule, Marbled Teal, and seven protected species of Ardeidae and two endemic species in the Hor-al-Azim marsh add to the its ecological value. For this reason, in 2011, the wetland has been added to the list of protected areas of Iran and it has been proposed for registration in the Ramsar Convention as an important international wetland [9]. Reduction of species diversity, elimination some globally threatened species, decreasing of populations of water birds and protected species since 2006 to 2016 has been shown in tables 1, 2, 3,4 . Reducing the biodiversity indices of swimmer water birds from February 2006 to February 2016 is evident in table 1. Table 4 shows that the highest Margalef diversity index was 2,264 in 2016 and the lowest was 0.684 in 2006, also the lowest Shannon-Wiener Diversity Index was 0.382 in 2006 and the highest was 2.242 in 2016. The highest Simpson's1-D evenness index was 2.084 in 2006 and its lowest value was 0.860 in 2016 for swimmer water birds. The Menhinick Diversity Index for all water birds in 2006 was 0.377 . Its highest level in 2011 was 6.092 . These changes are due to changes in the population and the area of the wetland. As the population increases and the number of species is constant, the evenness increases, and diversity decreases. The highest Dominance-D for all aquatic birds in 2011 was 0.268 and its lowest value in 2016 was 0.080 . The highest Evenness_e $\wedge$ H / $S$ in 2016, and the lowest in 2011, were 0.442 and 0.196 respectively. The number of swimmer water birds species in February, 2006, 2011, and 2016 was 21, 15, and 19, respectively (Table 1). Reductions and changes in the number of species and population of water birds in 2011 and in 2016 are not the same. Because the area of Hor-al-Azim was not the same in 2011 and 2016. The area of the marsh in 2011 was 5000 hectares and in 2016 it was reported at 10,000 hectares $[9,23]$. The decrease was in 2011 more than in 2016. Diversity, alpha and beta also decreased from 2006 to 2016 (Table 1). Beta variation, alpha diversity, and gamma diversity by Whittaker were presented in 1972. Based on the idea that species diversity in the landscape $(\gamma)$ is determined by two different criteria, namely, the average species diversity in the wetland $(\alpha)$ and the distinction between wetlands $(\beta)$. Beta variation is a disparity in the diversity among bird communities in wetlands, so diversity $(\beta)$ is also called habitat diversity [29]. The alpha and 
Citation: Behrouz BR (2019) Changes in community structure and species diversity of water birds as ecological indexes of Hor-al-Azim Marsh. J Aquat Res Mar Sci 2019: 134 -144.

\begin{tabular}{|c|c|c|c|c|c|c|c|}
\hline Scientific Name & $\begin{array}{l}\text { No } \\
006\end{array}$ & $\begin{array}{l}\text { Abundance } \\
2006\end{array}$ & $\begin{array}{l}\text { No. } \\
2011\end{array}$ & $\begin{array}{l}\text { Abundance } \\
2011\end{array}$ & $\begin{array}{l}\text { No. } \\
2016\end{array}$ & $\begin{array}{l}\text { Abundance } \\
2016\end{array}$ & $\begin{array}{c}\text { Population } \\
\text { Reduction } \\
\text { from } 2006 \\
\text { to } 2016\end{array}$ \\
\hline Grey Heron Ardea cinerea + & 193 & $1.04(2.53)$ & 2 & $0.08(1.29)$ & 56 & $1.43(5.19)$ & $70.91 \%$ \\
\hline Purple Heron Ardea purpurea + & 20 & $0.10(0.26)$ & 2 & $0.08(1.29)$ & 14 & $0.35(1.29)$ & $30 \%$ \\
\hline Great White Heron Cosmerodius albus + & 359 & $1.97(4.71)$ & 2 & $0.08(1.29)$ & 45 & $1.15(4.17)$ & $87.87 \%$ \\
\hline Little Egret Egretta garzetta + & 1570 & $8.56(20.61)$ & 23 & $1.01(14.83)$ & 98 & $3.50(9.09)$ & $93.76 \%$ \\
\hline Cattle Egret Bubulcus ibis + & 135 & $0.74(1.77)$ & 25 & $1.97(16.12)$ & 98 & $2.50(9.09)$ & $27.41 \%$ \\
\hline Squacco Heron Ardeola ralloides + & 121 & $0.66(1.58)$ & 6 & $0.24(3.87)$ & 21 & $0.53(1.94)$ & $82.65 \%$ \\
\hline $\begin{array}{l}\text { Black-crowned Night Heron Nycticorax } \\
\text { nycticorax }+\end{array}$ & 123 & $0.67(1.61)$ & 0 & $0(0)$ & 54 & $1.38(5.00)$ & $56.1 \%$ \\
\hline Sacred Ibis Threskiornis aethiopicus & 9 & $0.05(0.11)$ & 0 & $0(0)$ & 0 & $0(0)$ & $100 \%$ \\
\hline Glossy Ibis plegadis falcinellus & 30 & $0.16(0.39)$ & 10 & $0.44(6.45)$ & 12 & $0.30(1,11)$ & $60 \%$ \\
\hline Spoonbill Platalea Leucorodia & 195 & $1.06(2.56)$ & 0 & $0(0)$ & 4 & $0.10(0.37)$ & $97.95 \%$ \\
\hline $\begin{array}{l}\text { Brack-winged Stilt Himantopus hitman- } \\
\text { topus }\end{array}$ & 328 & $1.78(4.30)$ & 14 & $0.61(9.03)$ & 163 & $4.16(15.12)$ & $50.31 \%$ \\
\hline Recurvirostra avosetta & 228 & $1.21(2.99)$ & 14 & $0.61(9.03)$ & 111 & 2.83(1.29) & $51.32 \%$ \\
\hline Spur-winged Plover Vanellus spinosus & 4 & $0.02((0.05)$ & 1 & $0.04(0.64)$ & 6 & $0.15(0.55)$ & $\begin{array}{l}150 \% \text { in- } \\
\text { creased }\end{array}$ \\
\hline White-tailed Lapwing Vanellus leucurus & 220 & $1.20(2.88)$ & 14 & $0.61(9.03)$ & 156 & $3.99(14.47)$ & $29.1 \%$ \\
\hline Red-wettled Lapwing Vanellus indicus & 221 & $1.20(2.90)$ & 20 & $0 / 88(12.90)$ & 76 & $1.94(7.05)$ & $65.62 \%$ \\
\hline Ringed Plover Charadrius hiaticula & 210 & $1.15(2.75)$ & 1 & $0.04(0.64)$ & 31 & $0.79(2.87)$ & $85.24 \%$ \\
\hline Little Ringed Plover Charadrius dubius & 5 & $0.03((0.06)$ & 0 & $0(0)$ & 1 & $0.03(0.09)$ & $80 \%$ \\
\hline Kentish Plover Charadrius alexandrinus & 5 & $0.03(0.06)$ & 3 & $0.12(1.93)$ & 2 & $0.05(0.18)$ & $69 \%$ \\
\hline Eurasian Curlew Numenius arquata & 170 & $0.93(2.23)$ & 0 & $0(0)$ & 0 & $0(0)$ & $100 \%$ \\
\hline Black-tailed Godwit Limosa limosa & 123 & $0.67(1.61)$ & 10 & $0.44(6.45)$ & 12 & $0.30(1.11)$ & $90.25 \%$ \\
\hline Spotted Redshank Tringa erythropus & 85 & $0.46(1.11)$ & 2 & $0.8(1.29)$ & 12 & $0.30(1.11)$ & $85.89 \%$ \\
\hline Redshank Tringa totanus & 120 & $0.64(1.57)$ & 4 & $0.16(2.58)$ & 23 & $0.59(2.13)$ & $80.84 \%$ \\
\hline Marsh Sandpiper Tringa stagnatilis & 25 & $0.14(0.32)$ & 2 & $0.08(1.29)$ & 12 & $0.3(1.11)$ & $52 \%$ \\
\hline Common Greenshank Tringa nebularia & 80 & $0.43(1.05)$ & 0 & $0(0)$ & 6 & $0.15(0.55)$ & $92.5 \%$ \\
\hline Wood Sandpiper Tringa glareola & 15 & $0.08(0.19)$ & 0 & $0(0)$ & 0 & $0(0)$ & $100 \%$ \\
\hline Common Sandpiper Actitis hypoleucos & 3 & $0.01(0.03)$ & 0 & $0(0)$ & 0 & $0(0)$ & $100 \%$ \\
\hline Ruddy Turnstone Arenaria interpres & 15 & $0.08(0.19)$ & 0 & $0(0)$ & 0 & $0(0)$ & $100 \%$ \\
\hline Dunlin Calidris alpine & 750 & $4.09(9.84)$ & 0 & $0(0)$ & 0 & $0(0)$ & $100 \%$ \\
\hline Little Stint Calidris minuta & 2250 & $12.27(29.53)$ & 0 & $0(0)$ & 60 & $1.43(5.56)$ & $97.34 \%$ \\
\hline Temminck's Stint Calidris temminckii & 5 & $0.03(0.06)$ & 0 & $0(0)$ & 5 & $0.13(0.46)$ & stable \\
\hline Total 30 species & 7617 & 100 & 155 & 100 & 1078 & 100 & $85.85 \%$ \\
\hline
\end{tabular}

Table 3: Number and abundance of Shore birds (waders and wading) in Hor-al-Azim in 2006, 2011 and 2016

+ Protected Species in Iran

Numbers in parentheses are relative abundance of waders and wading birds in the same year and numbers outside of parentheses are relative abundance of warders and wading birds to total water birds in the same year. 
Citation: Behrouz BR (2019) Changes in community structure and species diversity of water birds as ecological indexes of Hor-al-Azim Marsh. J Aquat Res Mar Sci 2019: 134-144.

\begin{tabular}{|c|c|c|c|c|c|c|c|c|c|}
\hline \multirow{2}{*}{ Biodiversity indices } & \multicolumn{3}{|c|}{ Swimmer water birds } & \multicolumn{3}{|c|}{ Waders and Wading Birds } & \multicolumn{3}{|c|}{ Total Number of Birds } \\
\hline & 2006 & 2011 & 2016 & 2006 & 2011 & 2016 & 2006 & 2011 & 2016 \\
\hline Dominance-D & 0.810 & 0.313 & 0.140 & 0.150 & 0.124 & 0.088 & 0.091 & 0.268 & 0.080 \\
\hline Simpson_1-D & 2.084 & 0.686 & 0.86 & 0.849 & 0.875 & 0.911 & 0.909 & 0.732 & 0.92 \\
\hline Shannon_H & 0.382 & 1.528 & 2.242 & 2.418 & 2.383 & 2.658 & 2.902 & 1.864 & 2.944 \\
\hline Evenness_e^ $\mathrm{e}^{\wedge} / \mathrm{S}$ & 2.078 & 0.307 & 0.495 & 0.374 & 0.602 & 0.594 & 0.357 & 0.196 & 0.442 \\
\hline Brillouin & 0.202 & 1.511 & 2.225 & 2.407 & 2.22 & 2.607 & 2.893 & 1.835 & 2.916 \\
\hline Menhinick & 2.155 & 0.327 & 0.356 & 0.343 & 1.361 & 0.732 & 0.377 & 0.692 & 0.688 \\
\hline Margalef & 0.684 & 1.83 & 2.264 & 3.245 & 3.292 & 3.296 & 5.093 & 4.139 & 5.078 \\
\hline Equitability_J & 2.512 & 0.564 & 0.761 & 0.711 & 0.824 & 0.836 & 0.738 & 0.533 & 0.783 \\
\hline Fisher_alpha & 0.361 & 2.183 & 2.736 & 3.968 & 5.032 & 4.354 & 6.407 & 5.469 & 6.759 \\
\hline Berger-Parker & 0.810 & 0.466 & 0.230 & 0.295 & 0.257 & 0.151 & 0.211 & 0.431 & 0.167 \\
\hline
\end{tabular}

Table 4: Biodiversity indices of all water birds in Hor-al-Azim in 2006. 2011 and 2016

beta variation of swimmer water birds in Hor-al-Azim marsh decreased $15.69 \%, 60.29 \%$ from 2006 to 2016 , respectively. Despite the decline in the diversity and population of water birds, a number of swimmer water birds and migratory water birds are migrating to Hor-al-Amiz marsh yet. For this reason, there is a similarity of $49.53 \%$ between the all water birds in 2006 and 2016 . But changes in the diversity and population of water birds from 2006 to 2016 have led to a Euclidean difference of 6,157.87. Reducing waders and wading birds is due to the destruction of the habitats of the margin of the wetland and shallow parts of it, which is an appropriate habitat for the shore birds, but due to the drying most part of the wetland and converting of marginal land into agricultural land, The diversity of habitats of waders and wading birds has completely disappeared and has reduced the population and diversity of shore birds, tables 2 and 4 and Figure 4 show these changes. The population and diversity of all water birds also decreased from 2006 to 2016 due to changes in the area of the wetland and the amount of water, the reduction of habitat diversity and possibly other factors such as security in the wetland (Table 2). The area of the wetland in Iran in 2006 was 118,000 hectares, but in 2011 it decreased to 5000, however, in 2016 , by dewatering the wastewater of the region and slightly from the Karkheh River, it increased to 10,000 hectares [9], and the number of water birds and their diversity have also been changed by reducing and increasing the area of the wetland. Number of all water birds and species diversity increased from 2011 to 2016 (Table 1). Similar study had been carried out by Behrouzi-Rad in 2009 in Hamoon wetland and reported, the population changes in the water birds in relation the fluctuation of amount of water in the Hamoon and concluded that the diversity and number of water birds in the wetland is related to the depth of water and wetland area. Reducing the depth and area of the wetland decreases the diversity and number of all water birds. With fluctuations in the water level and the area of the Hor-alAzim marsh, from 2006 to 2016, the population and diversity of water birds in the wetland have fluctuated and decreased, and this decrease has been higher in the fish-eating bird's population, such as Greater Cormorant decreased from 1720 to 12 individuals. Reduction was $99.32 \%$. The population of Great Crested Grebe decreased from 58 to 12 individuals, reduction was $32.29 \%$ in 2016. In similar studies by Bechir et al in 2013, 88 species of waterirds reported in water ecosystem including 42 large dams reservoir, 41 small dams reservoir, and 20 natural wetlands, and reported 48 species of water birds in natural wetlands and 41 species in dam reservoirs. The number of water birds in the safe and natural wetlands was more than damaged wetlands [17]. In 2006, the Hor-al-Azim had area of 118,000 hectares and had numerous securities and was suitable habitats for water birds. The number of species and population was higher than in the years 2011 and 2016 (Table 1). Rotenberry (1985) studied the role of habitat in the composition of water birds populations, it has been concluded that the composition of the water birds population of wetlands is related to the natural and security of habitat. Because each group of birds prefers a specific part of a water habitat in relation to vegetation, food, security, and other environmental factors [19]. The results of the study of the water birds in the Horal-Azim confirmed that result. Moula and Makvandi (2008) reported 86 species of water birds in the Hor-al-Azim [23]. In 2011, the number of species decreased to 43, less than half in 2016. In a similar study Khalilipour and Behrouzi-Rad (2009) investigated the relation between the diversity and number of water birds in the southern wetlands of the Caspian Sea, and concluded that in larger wetlands, species diversity and number of water birds were higher than small wetlands [23]. This result confirms the results obtained from the study of water birds in Hor-al-Azim. Yazdan-Dad (2011) has reviewed variations, abundance, and diversity of water birds in water ecosystems in Khorasan Razavi province and reported that in larger wetlands, the number of species and population of water birds were higher [31]. This result confirms the results obtained from Hor-al-Azim. Amat and Green (2010) reported that population changes and water birds species variation are affected by the quality of the environmental factors in the wetlands, such as water content and depth of water. He was concluded that the changes in the popu- 
lation and diversity of water birds species are the indicator of the environmental health of the wetlands [1]. That findings are similar to and consistent with the results obtained from Hor-alAzim. Behrouzi-Rad (2016) studied the effect of water reducing of Urmia Lake on species diversity and population of water birds in Kaniborazan wetland and concluded that the decrease in water of Lake Urmia has reduced the species diversity and the populations of water birds of the Kaniborazan wetland [31]. Review of all published articles shows that diversity and populations of water birds are related to the status of the wetland environment and are an ecological indicator. Table 1 show the decrease in the area of the Hor-al-Azim and the loss of factors such as security, amount of water, food availability and etc. has led to a reduction in water birds population and species diversity. This decrease is due to the changing ecological conditions of the Hor-al-Azim. Therefore, it is essential to carry out maximum effort in the identification biodiversity of the country conservation sites and preservation of the endangered species which includes water birds and other wildlife.

\section{Conclusion}

Hor-al-Amiz is part of Mesopotamian marshes, more than two thirds of which are located in Iraq. The area of the Hor-al-Amiz marsh varies from 500000 to 300000 hectares. The area of wetland was 118,000 in 2006, less than 5000 hectares in 2011 and about 10,000 hectares in 2016 in Iran. Drying of Hor-alAzim wetland, lack of connection between different parts of Mesopotamian marshes and Hor-al-Azim, fragmentation of Hor-al-Azim due to the construction of drainage channels, Seizure of wetland grounds, land allocation of northern part of it to farmers as rice fields, wheat, drilling oil wells in the marsh, construction of roads in the marsh, illegal fishing and hunting with the construction of rick hunting in the marsh, trips among marsh, grazing of livestock inside the marsh, especially in the spring, easy access to the marsh, entry of fertilizers and pesticides into the marsh by west waters, harvesting of aquatic plants including "Reed" and " forage", Unpacking the wetland by building roads for extraction of petroleum, the lack of applied rehabilitation programs, prevention of water entry across the marsh and the prevention of water exchange between its different parts, the establishment of unauthorized livestock units in most northern part of marsh, failure to manage wastewater entering to the marsh, burning of reeds, and evacuation of oil waste in the wetland, finally, drought is one of the most important threats and changes in the ecological function of the Hor-al- Azim marsh. These factors have reduced the area of the wetland from 118,000 hectares in 2006 to 10,000 hectares in 2016. Reducing the area of the wetland has reduced the biodiversity index of water birds, population structure and species diversity (Table 4). Wetland drying and reducing its area has reduced the population, diversity, and density of water birds. As shown in Table 1, the decrease in the number of swimmer water birds was $73.55 \%$, species number was $9.33 \%$, population of shore birds was $85.85 \%$ species number of shore birds was $20 \%$, total population of water birds was $78.68 \%$, and their species number was $11.26 \%$. The water birds are more dependent on the wetland, Their population and diversity varies more by changing the ecological conditions of the wetland. As shown in Table 1, population decline and species diversity of shore birds were higher than swimmer water birds. Because shore are dependent on fish and benthos's in terms of nutrition, due to the drying of the wetland, the proper conditions for feeding and the source of food for shore birds have been reduced. As shown in Table 4, Margalef and Berger-Parker diversity indexes declined from 5.093 to 5.078 and 0.211 to 0.167 respectively. Against the decline in species diversity, the evenness index has increased from 0.375 to 0.44 . As shown in table 2 , the reduction of each swimmer water birds species population fluctuated between $100 \%$ and $7.7 \%$. The highest reduction was found in two species of shelduck and Ferruginous Duck (100\%), and the lowest reduction was in Pintail population (7.7\%). Only population of 4 species of Mallard, Gadwall, Eurasian Wigeon, and Common Moorhen increased. Their increase was 1.95, 2.07, 6.15, and 6.42 time respectively. As shown in table 3, the fluctuation range of the population reduction of shore birds was between $30 \%$ and $100 \%$. Of the shorebirds, only the population of Spur-winged Plover has increased 1.5-fold. Population of 4 species, Wood Sandpiper, Common Sandpiper, Ruddy Turnstone and Dunlin decrease $100 \%$ Timmins's Stint population was stable and the population of Purple Heron had the lowest decrease (\% 30). In the absence of attention and planning to protect and manage the ecosystem of the wetland and its restoration, a small number of remaining water birds and other wildlife dependent on the wetland will also be eliminated. More importantly is the lack of restoration of the wetland has increased dust storm in the region, because the ecosystem of the Hor-al Azim and the Mesopotamian marshes plays an important role in protecting the wetland birds and reducing dust storm in the region. Drying the Mesopotamian marshes both in Iran and in Iraq has increased the amount of sand storms that has caused the Khuzestan province to reach about 21 times more than health standards with dust [9]. Reduced area of the marsh from 118,000 hectares in Iran in 2006 to less than 10000 hectares in 2016 caused a decrease of $78.68 \%$ of the population and $26.11 \%$ of the species of water birds. As a result, change in the ecological conditions of the wetland has caused changes in the population and the diversity of water birds. Therefore, water birds are excellent bio indicators of health of biodiversity as well as particular habitat and its productivity. They are also important in monitoring environmental changes because of their ecological diversity. All these changes indicate that aquatic birds are an indicator of the ecological conditions of wetlands. Population stability and species diversity depend on the sustainable conditions of the wetland. Therefore, the ecological sustainability conditions have decreased in Hor-al-Azim Wetland, which has reduced population and diversity of birds. For this reason, aquatic birds are the ecological indicator of wetlands. 
Citation: Behrouz BR (2019) Changes in community structure and species diversity of water birds as ecological indexes of Hor-al-Azim Marsh. J Aquat Res Mar Sci 2019: 134-144.

\section{References}

1. Amat JA, Green A J (2010) Water birds as bio-indicators of environmental conditions, Conservation monitoring in freshwater habitat, a practical guide and case studies, Edited by Hurford, C. Schneider M., and Cown, L., Springer Dordrecht Heidelberg London New York.

2. Behrouzi-Rad B (2008) Wetlands of Iran. Published by Department of Geographical of Iran army of Islamic Republic Iran, Pp.39-93. (In Persian).

3. Behrouzi-Rad B (2009) Water bird populations during dry and wet years in the Hamoon Wetlands Complex, Iran, /Afghanistan Border, Prodces 2: 88-99.

4. Partow H (200) The Mesopotamian marshlands: Demise of an ecosystem. Division of early warning and assessment, United Nation Environment Program (UNEP) Pp.38.

5. Behrouzi-Rad B (2011) Wetlands Management, Khuzestan Science, and Research campus, Islamic Azad University, Pp309. (In Persian).

6. Behrouzi RB (2018) Breeding population of Terns and Western Reef Heron on Ghabre Nakhoda and Dara Islands, in Persian Gulf in 2003,2009,2012,2016. Open Acc J Envi Soi Sci 1: 106-115.

7. Behrouzi RB (2014) Species and breeding population water birds on four islands in Khore Mosa in Persian Gulf in 2003 and 2012. J Ecol Nat Environ 6: 99-110.

8. Ramsar Convention Bureau (2015) Ramsar information Sheet.

9. Department of Environment of Khuzestan Province (2016)

10. Evans MI (1994) Important bird area in the Middle East, Published by UK Pp. 31-156

11. Kiabi BH, Majnonian H, Meighoni HG, Mansoori J (2004) Indicators of Iranian wetlands based on water birds population valuation. Department of Environment of Iran. Unpublished Report Pp.35 (In Persian).

12. Scott D A (2008) rare birds in Iran in the late 1960s and 1970s. Podoces 3: 1-30

13. IUCN (2010) Red List of Threatened Animals, IUCN, Switzerland.

14. Pandam Consultant Engineering (2006) Study of natural environment of Hor-al-Azim wetland, Unpublished Report Pp. 250 pp. (In Persian and English).

15. Behrouzi-Rad B (2013) Comparison of species number and population of breeding water birds in Lake Urmia in 1981and 2011, J Environ Res 8: 195-204, (In Persian).

16. Department of Environment of Iran (2000) Law and environmental regulations, Published by Law Office and Parliamentary Affairs,
Vil.1Pp.198-209 (In Persian).

17. Bechir A, Faouzia CC, Aissa M (2013) Tunisian man-made wetlands as alternative habitats for water birds and their role for conservation. African J Ecol 10:12-20.

18. Musgrove A J, Austin GE, Hearn RD, Holt CA, Stroud A, Wotton SR (2011) over winter population estimates of British water birds. J British Birds 104: 364-397.

19. Rotenberry $\mathrm{T}(1985)$ the role of habitat in avian community composition, Physiognomy or Floristic?. Ecologies 2: 402-402.

20. Torres R (1995) Waterfowl community structure of Laguna Santo Domingo (Cordoba) during and annual cycle. Rev Asoc Cinch Nat Litor st Tome 26: 33-40.

21. Yahkat B, Birgit, Les GU, Res A (2017) Identifying ecological and life-history drivers of population dynamics of wetland birds in South Africa. Global Ecol Conser12: 96-107.

22. Khalilipour A, Behrouzi-Rad B (2007) Investigation of species diversity and population composition of water birds in coastal wetlands of Caspian Sea. J Environ Sci 44: 20-26.

23. Moula A, Makvandi M (2008) Characteristics of the Hor-al-Azim wetland. Published by Department of Environment of Khuzestan Province Pp. 19.

24. Aazami J, Nafar R A (2018) Contrasting changes in the abundance and diversity of Northern Iranian birds' assemblages from 2011 to 2015. J Asia-Pacific Biodiver 11: 334-339.

25. Farashi A, Halakouhi L (2018) Migratory waterfowls as indicators to assess the protection efficiency in Iran. Acta Ecologica Sinica 38: 429-443.

26. Wetlands International (2006) Water bird population estimates, 4th Edition, Wetlands International, Wageningen. Pp. 320.

27. Bhushan B, Fry G, Hibi A, Mundaker T, Prawiradilaga DM, Sonobe K, Usui S (1993) A Field guide to the water birds of Asia, Published by Wild Bird Society of Japan Pp. 224.

28. Hammer $\varnothing$, Harper DAT, Ryan PD (2012) Paleontological Statistics Software (PAST) Package for Education and Data Analysis, Natural History Museum University of Oslo Pp.135-148.

29. Whittaker $\mathrm{RH}(1972)$ Evolution and measurement of species diversity. J Taxon 21: 213-223.

30. Yazdan-Dad H (2011) Investigation of species diversity and population changes of water birds in water ecosystems of Khorana Razavi Province, Animal Environment, 45-58. (In Persian).

31. Behrouzi-Rad B (2016) Effect of water reducing of Urmia Lake on species diversity and population of water birds in Kaniborazan wetland at 1995, 2005 and 2015, J Environ Res 41: 59-70 (In Persian). 


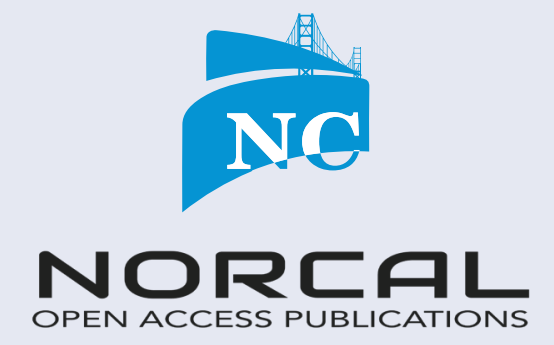

submit your manuscripts at

www. norcaloa.com 